\title{
Productivity enhancements of compound parabolic concentrator tubular solar stills
}

\begin{abstract}
The performance of compound parabolic concentrator assisted tubular solar still (CPC-TSS) and compound parabolic concentrator-concentric tubular solar still (CPC-CTSS) (to allow cooling water) with different augmentation systems were studied. A rectangular saline water trough of dimension $2 \mathrm{~m} \times 0.03 \mathrm{~m} \times 0.025 \mathrm{~m}$ was designed and fabricated. The effective collector area of the still is $2 \mathrm{~m} \times 1 \mathrm{~m}$ with five sets of tubular still $\ddot{i}$ CPC collectors placed horizontally with north-south orientation. Hot water taken from the CPC-CTSS was integrated to a pyramid type and single slope solar still. Diurnal variations of water temperature, air temperature, cover temperature and distillate yield were recorded. The results showed that, the productivity of the un-augmented CPC-TSS and CPC-CTSS were 3710 $\mathrm{ml} /$ day and $4960 \mathrm{ml} /$ day, respectively. With the heat extraction technique, the productivity of CPC-CTSS with a single slope solar still and CPC-CTSS with a pyramid solar still were found as $6460 \mathrm{ml} /$ day and $7770 \mathrm{ml} /$ day, respectively. The process integration with different systems cost was found slightly higher but the overall efficiency and the produced distilled water yield was found augmented.
\end{abstract}

Keyword: Compound parabolic concentrator; Single slope solar still; Pyramid solar still; Cooling water 